\title{
Safety distances of cylindrical reinforced concrete piers under vehicle explosion
}

Zhao Zhu MEng

PhD student, School of Highways, Chang'an University, Xi'an, China (Orcid:0000-0003-0807-1885) (corresponding author:

zhaoz1992@163.com)

Yuan Li DE

Lecturer, School of Highways, Chang'an University, Xi'an, China
Shuanhai He DE

Professor, School of Highways, Chang'an University, Xi'an, China

Since the terrorist attacks on 11 September 2001, structural resistance to explosion has received increasing attention. As bridges are controlling factors in traffic systems, explosion-induced bridge damage will cause great economic loss and social impact, but there is a lack of anti-explosion research for bridges. The purpose of this work was to investigate the failure modes and safety distances of cylindrical reinforced concrete (RC) bridge piers on highways and urban viaducts as a result of vehicle explosion. TNT equivalents were selected to represent explosions of five different vehicles (car, sport utility vehicle/van, delivery truck, water truck and semi-trailer). The multi-Euler domain method, was adopted for structural analysis of the explosion process using the commercial software Autodyn. The results showed that RC piers have three failure modes at the base: full-section punching-shear failure and large displacement; shear failure of full-section concrete; local shear failure of concrete. The explosion energy decayed rapidly with distance. For the five vehicle explosions, the safety distances were found to be $2 \mathrm{~m}, 3 \mathrm{~m}, 4 \mathrm{~m}, 8 \mathrm{~m}$ and $14 \mathrm{~m}$, respectively. The results of this work are meaningful for explosion-resistant design and damage assessments of existing highway cylindrical RC piers subjected to vehicle explosion.

\section{Notation}

$\begin{array}{ll}A & \text { initial yield stress } \\ A_{\mathrm{s}} & \text { area of section } \\ B & \text { hardening constant } \\ C & \text { strain rate constant } \\ E & \text { elastic modulus of concrete } \\ E_{\mathrm{O}} & \text { internal energy of unit volume } \\ e & \text { internal energy } \\ f_{\mathrm{c}} & \text { concrete compressive strength } \\ f_{\mathrm{s}} & \text { concrete shear strength } \\ f_{\mathrm{t}} & \text { concrete tensile strength } \\ G & \text { shear modulus of concrete } \\ m & \text { thermal softening exponent } \\ n & \text { hardening exponent } \\ p & \text { pressure during explosion } \\ T_{\mathrm{H}} & \text { homologous temperature } \\ V & \text { volume ratio } \\ Y & \text { yield stress } \\ \gamma & \text { adiabatic exponent of ideal air } \\ \varepsilon_{\mathrm{p}} & \text { effective plastic strain } \\ \varepsilon_{\mathrm{p}}^{*} & \text { normalised effective plastic strain rate } \\ \rho & \text { density }\end{array}$

\section{Introduction}

Over the past 60 years, more than 550 terrorist attacks on bridges and buildings have been recorded (Pan et al., 2017). Bridges are often the targets for terrorist attacks because of their large volume, great social impact and accessibility. As components supporting bridge superstructures, piers transfer dead load and live load to the foundation. The destruction of bridge piers thus leads directly to bridge damage, resulting in excessive displacement of the superstructure or even collapse, affecting traffic safety and causing adverse social impacts. Damage evaluation and the safety distance of reinforced concrete (RC) piers of highway bridges during intentional and unintentional vehicle explosion are urgent issues for research.

Williamson et al. (2011a, 2011b) studied the influence of crosssectional shape, length/depth ratio, and volume reinforcement ratio on the anti-explosion performance of bridges with ten different half-scale columns. Their results showed that the damage mode was base shear failure in cases the explosive charge was close to the ground. They proposed that the antiexplosion design of piers should be improved by $50 \%$, with the transverse reinforcement ratio corresponding to the seismic design of piers.

Zong et al. (2017) investigated $11 \mathrm{RC}$ piers during mid-field explosion and contact explosion, and formulated a relationship between the peak overpressure and proportional distance. Their results showed that, under non-contact explosion, an increase in the section area of the pier, the use of concrete reinforced with steel fibres, a square section form and spiral stirrups reduced the cross-section strain and restrained cracks. Under the action of contact explosion, RC piers can easily be punched and destroyed at the contact position. A square section and the axial force under the action of contact explosion are unfavourable to the explosion resistance of piers.

Based on existing piers, Liu et al. (2018) studied the bending failure modes of RC piers at their bottom, mid-height and top. 


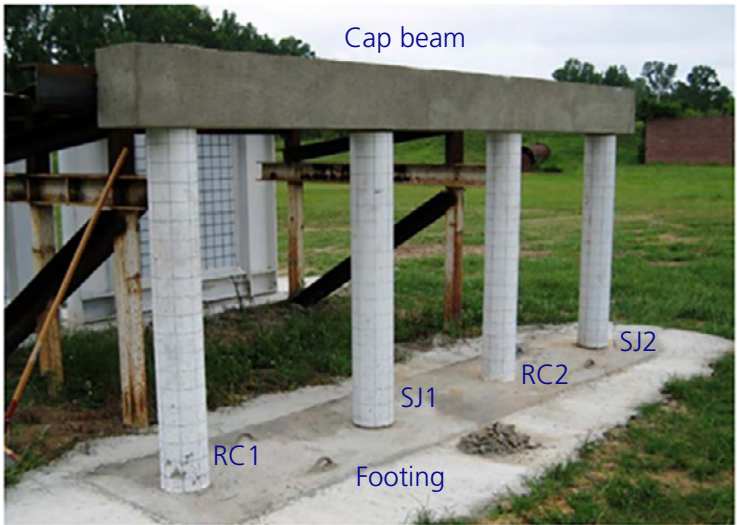

(a)

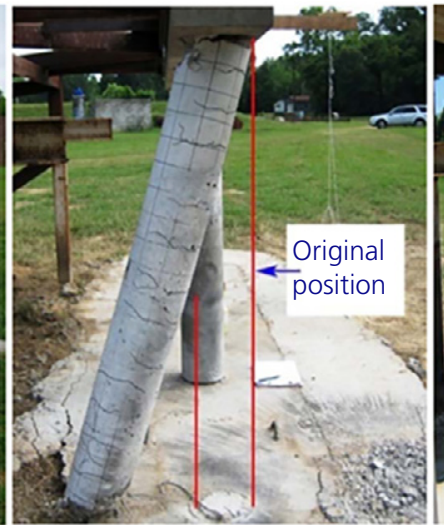

(b)

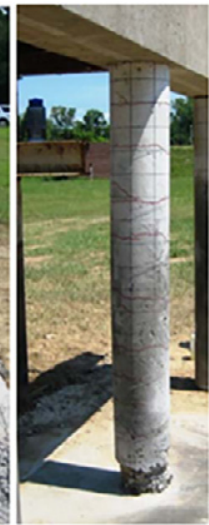

(c)

Figure 1. (a) Front diagonal view of test setup of Fujikura and Bruneau (2011); (b) failure mode after contact explosion; (c) failure mode after non-contact explosion

The damage status of the piers was evaluated using loaddisplacement curves of the piers before and after explosion. Thomas et al. (2018) investigated the structural reliability of circular RC bridge columns subjected to blast loading and sequential vehicular impact and explosive blast loading. The results showed that structural reliability under blast loading was highly sensitive to the diameter, reinforcement ratio and standoff distance.

Many scholars have studied explosion damage to single column piers using scale models and numerical analysis, and methods for the evaluation of explosion damage and design methods for explosion resistance have been proposed (Bao and Li, 2010; Kyei and Braimah, 2017; Li et al., 2017a, 2017b; Williams and Williamson, 2012). However, these methods ignore damage to the bent cap and the superstructure and simplify the boundary, meaning that the results obtained differ from real situations. Liu et al. (2015) investigated the damage mechanism of typical highway bridges under simplified blast loading. Fujikura and Bruneau (2011) reported the blast resistance of RC piers which met the requirements of seismic design. They concluded that seismically designed RC columns did not exhibit ductile behaviour under blast loading and failed in shear at the base rather than flexural yielding, as shown in Figure 1.

The energy release path of an explosive shock wave is directly related to the boundary form and structural size. Scaled models and simplified boundaries will therefore result in structural damage states different to those actually observed. The TNT equivalents of vehicle explosions are very large and experiments come with high risk and testing difficulty. Therefore, in the work reported in this paper, a numerical model was developed to evaluate the effects of vehicle explosions on columns and bent caps. TNT equivalents were selected to present an explosion of a car, sport utility vehicle (SUV)/van, delivery truck, water truck and semi-trailer. Based on the section and reinforcement ratio of piers in existing seismic design for highway bridges (Ministry of Transport of the People's Republic of China, 2018; Ministry of Transport of the People's Republic of China, 2008), the damage status structure was evaluated according to the damage area, the damage degree and the failure mode of the pier concrete and the reinforcement. The safety distances of cylindrical $\mathrm{RC}$ piers during various vehicle explosions were also derived. These are presented in this paper and can be used as a reference for anti-explosion design, protection and evaluation of explosion damage for cylindrical RC piers.

\section{Material properties and modelling}

Due to the high risks involved in explosion tests (Fujikura and Bruneau, 2011; Williamson et al., 2011a, 2011b; Zong et al., 2017), numerical simulations become important methods to conduct research on structures under blast loads (Carta and Stochino, 2013; Li and He, 2018). Pan et al. (2017) used the commercial software Autodyn to carry out numerical analysis of the explosion resistance of a cable-stayed bridge

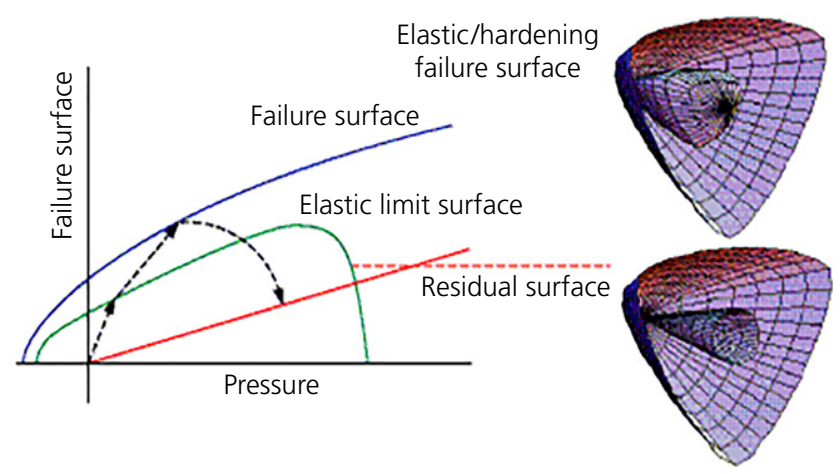

Figure 2. The Riedel-Hiermaier-Thoma concrete model 
and a steel-concrete composite girder bridge. $\mathrm{Li}$ and $\mathrm{He}$ (2018) analysed explosive loads on and under a steel-concrete composite girder bridge and used a numerical method to

Table 1. Material parameters of concrete

\begin{tabular}{ccccc}
$\boldsymbol{f}_{\mathrm{c}}: \mathbf{M P a}$ & $\boldsymbol{f}_{\mathrm{t}} / \boldsymbol{f}_{\mathrm{c}}$ & $\boldsymbol{f}_{\mathrm{s}} / \boldsymbol{f}_{\mathrm{c}}$ & $\boldsymbol{E}: \mathbf{M P a}$ & $\boldsymbol{G}: \mathbf{M P a}$ \\
\hline 40 & 0.1 & 0.18 & 32500 & 13000 \\
\hline
\end{tabular}

Table 2. Material parameters of the Johnson-Cook equation

\begin{tabular}{|lcccc|}
\hline A: MPa & B: MPa & C & $\boldsymbol{n}$ & $\boldsymbol{m}$ \\
\hline 345 & 424 & 0.26 & 0.014 & 1.03 \\
\hline
\end{tabular}

Table 3. Material parameters of air

\begin{tabular}{|llc|}
$\rho: \mathbf{g} / \mathbf{c m}^{\mathbf{3}}$ & $\mathbf{e}: \mathbf{J} / \mathbf{k g}^{\mathbf{1}}$ & $\boldsymbol{\gamma}$ \\
0.00125 & $2.068 \times 10^{8}$ & 1.4 \\
\hline
\end{tabular}

ascertain the damage area and structural stress distribution. Li et al. (2017b) performed a numerical study of a precast segmental column under blast loads using the hydro-code LSDyna. Validation of numerical methods has been shown by experiments by many scholars (Carta and Stochino, 2013; Shiravand and Parvanehro, 2017; Son and Astaneh-Asl, 2017).

\subsection{Material constitutive model}

A high-temperature field and high strain rate are commonly observed when structures are subjected to blast loads (Forni et al., 2017), which respectively result in concrete weakening and enhancement. Analytical accuracy is dependent on the concrete constitutive law. The Riedel-Hiermaier-Thoma (RHT) concrete model, validated by $\mathrm{Tu}$ and $\mathrm{Lu}$ (2010), was used in this study. The model is shown in Figure 2. The concrete parameters used in this work are shown in Table 1.

Besides the concrete constitutive law, the steel constitutive model of the stirrups and longitudinal steel bars directly affects the shear and flexural capacity of bridge columns. After comparison with experimental results and numerical

Table 4. Material parameters of the Jones-Wilkins-Lee state equation

\begin{tabular}{ccccccccc}
$\boldsymbol{R}_{\mathbf{1}}$ & $\boldsymbol{R}_{\mathbf{2}}$ & $\boldsymbol{A}: \mathbf{M P a}$ & $\boldsymbol{B}: \mathbf{M P a}$ & $\boldsymbol{\omega}$ & $\boldsymbol{\rho}: \mathbf{g} / \mathbf{c m}^{\mathbf{3}}$ & $\boldsymbol{V}$ & $\boldsymbol{E}: \mathbf{J} / \mathbf{k g}$ \\
\hline 4.15 & 0.90 & $3.378 \times 10^{5}$ & $3.747 \times 10^{3}$ & 0.35 & 1.63 & 1.00 & $7.0 \times 10^{6}$
\end{tabular}
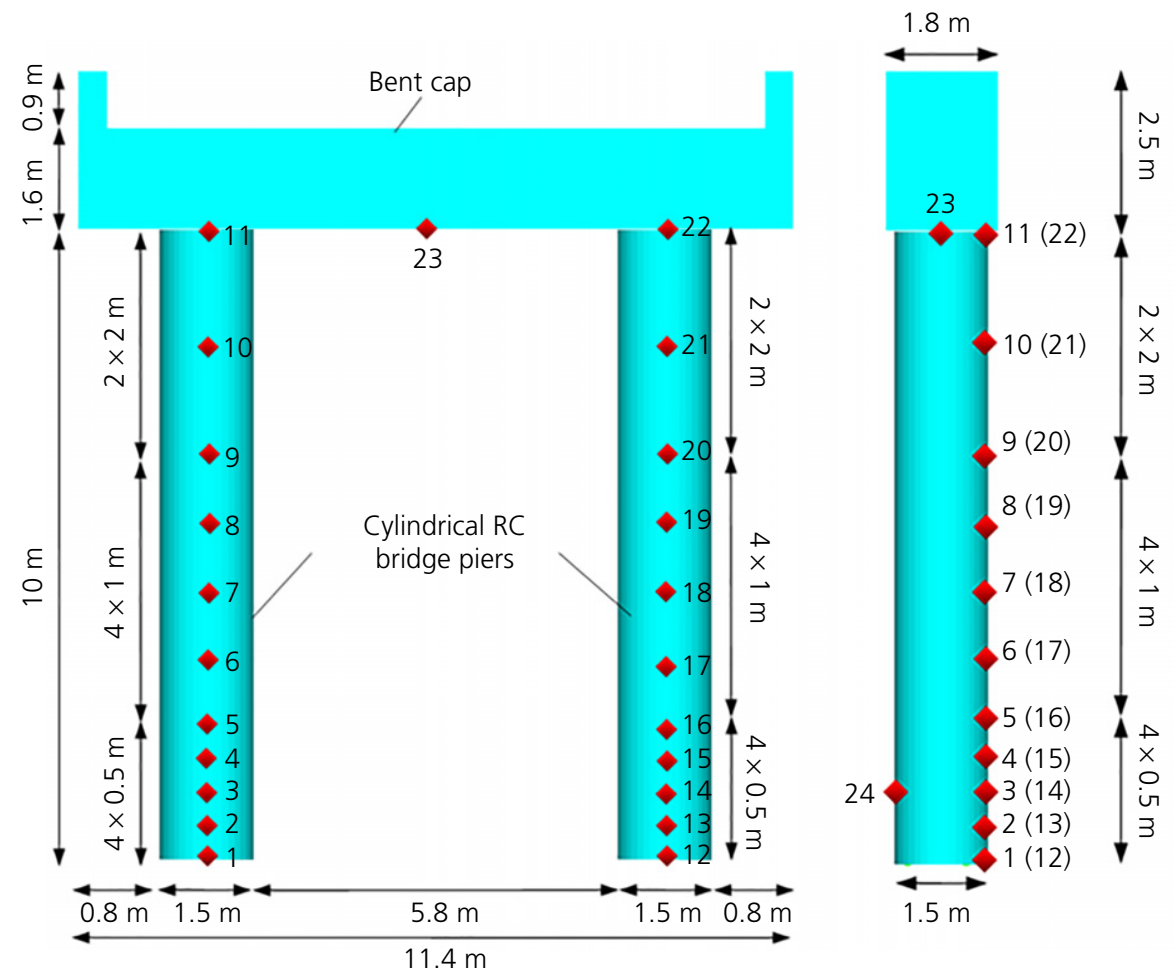

Figure 3. Arrangements of gauges 


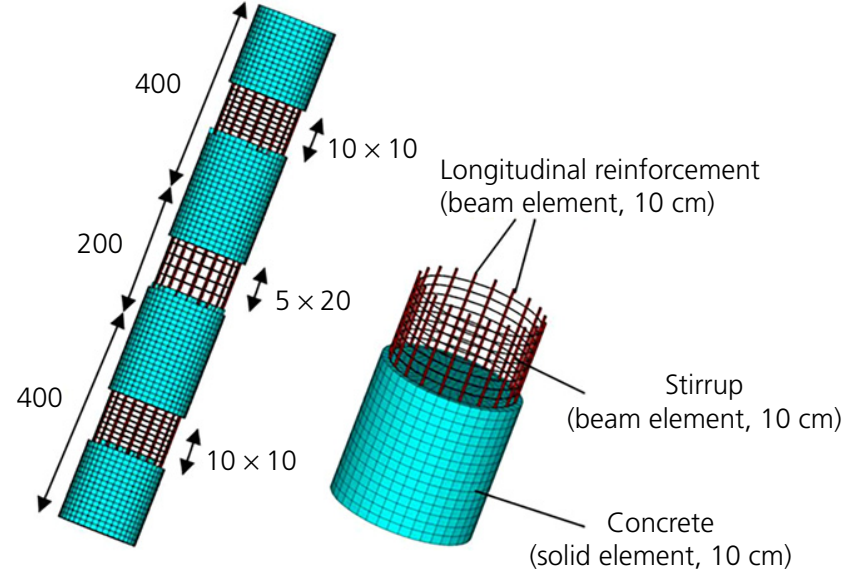

Figure 4. Arrangements of reinforcements in pier (dimensions in $\mathrm{cm}$ ) simulations performed by Forni et al. (2016), the JohnsonCook model was found to simulate precisely the strain-stress properties of steel during explosion. The model defines the yield stress $Y$ as:

$$
\text { 1. } Y=\left(A+B \varepsilon_{\mathrm{p}}^{n}\right)\left(1+C \ln \varepsilon_{\mathrm{p}}^{*}\right)\left(1-T_{\mathrm{H}}^{m}\right)
$$

The parameters was indicated in Table 2. Many scholars have defined $B$ to be 1.23A (Hashemi et al., 2017; Li et al., 2017a; Nystrom and Gylltoft, 2011).

To reflect standard atmospheric pressure, air was simplified to be ideal air:

\section{2. $p=(\gamma-1) \rho e$}

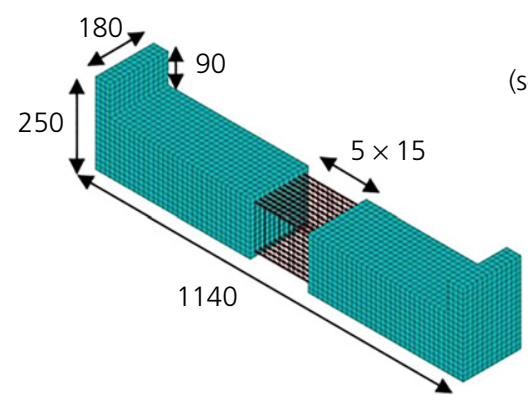

Concrete

(solid element, $15 \mathrm{~cm}$ )

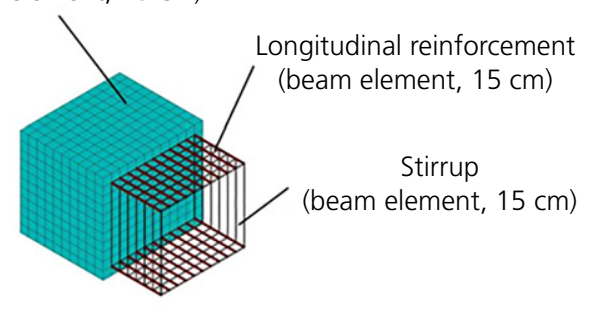

Figure 5. Arrangements of reinforcements in bent cap (dimensions in $\mathrm{cm}$ )

Table 5. Impact heights and TNT equivalents of representative vehicle classes (Thomas et al., 2018)

\begin{tabular}{|c|c|c|c|}
\hline \multirow[t]{6}{*}{ Vehicle } & & Impact height: $\mathbf{m}$ & TNT equivalent: $\mathbf{k g}$ \\
\hline & Car & 0.61 & 227 \\
\hline & SUV/van & 0.91 & 454 \\
\hline & Delivery truck & 1.22 & 1814 \\
\hline & Water truck & 1.5 & 4536 \\
\hline & Semi-trailer & 1.8 & 27215 \\
\hline
\end{tabular}


where $e, \gamma$ and $\rho$ are the internal energy, adiabatic exponent and density, respectively. These parameters are listed in Table 3.

To simulate energy transmission factually, the Jones-WilkinsLee state equation was adopted to model the explosive material and ambient air with the flow-out boundary condition. This equation is:

3. $p=A\left(1-\frac{\omega}{R_{1} V}\right) \mathrm{e}^{-R_{1} V}+B\left(1-\frac{\omega}{R_{2} V}\right) \mathrm{e}^{-R_{2} V}+\frac{\omega E_{0}}{V}$

The values of these parameters are shown in Table 4 .

\subsection{Finite-element modelling}

Autodyn is an explicit analysis tool for modelling the nonlinear dynamics of solids, fluids, gases and their interactions

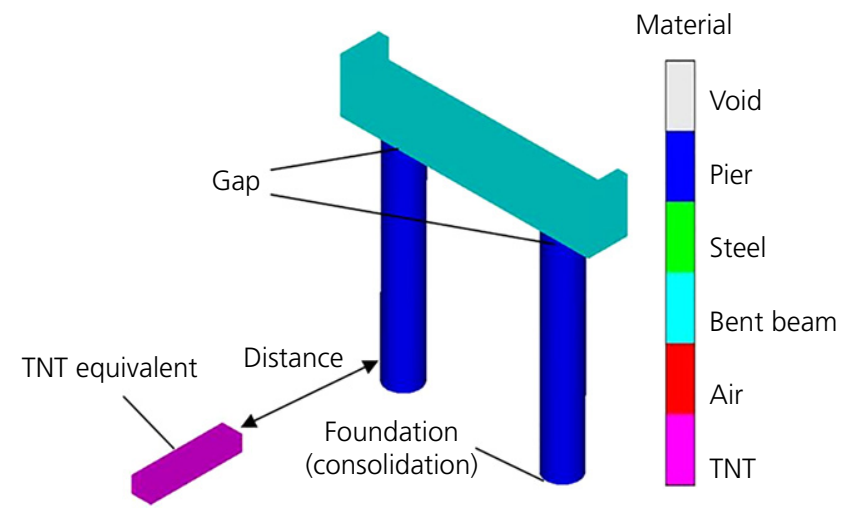

Figure 6. Analysis model in Autodyn. A full-colour version of this figure can be found on the ICE Virtual Library (www. icevirtuallibrary.com)

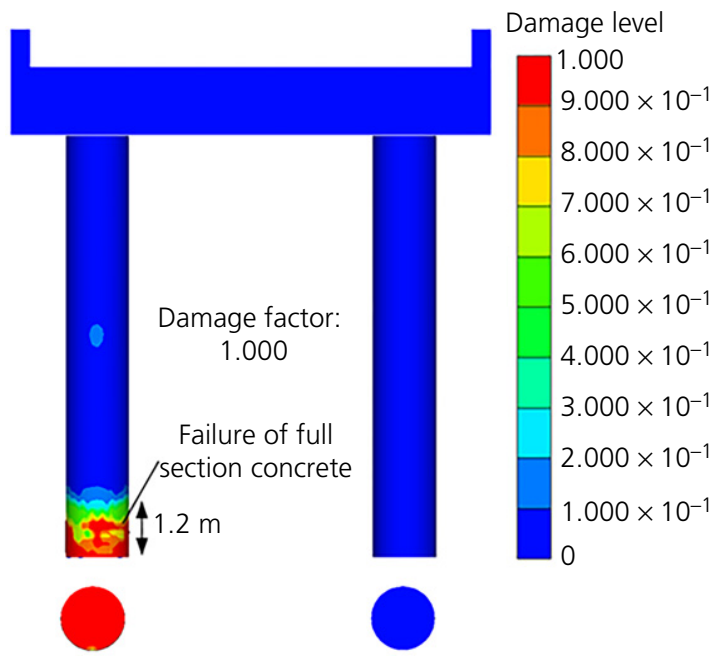

(a)
(Zhu et al., 2019). The accuracy of this analytical method has been verified by several researchers ( $\mathrm{Li}$ and $\mathrm{He}, 2018$; Pan et al., 2017; Winget et al., 2005). To balance accuracy and analytical time, the element sizes of the piers and bent cap were set to $10 \mathrm{~cm}$ and $15 \mathrm{~cm}$, respectively (Pan et al., 2013). Solid164 elements were adopted for the concrete while the reinforcement was modelled using Beam161. The RC piers were selected to be $10 \mathrm{~m}$ high and $1.5 \mathrm{~m}$ in diameter to represent bridge piers existing extensively in highway bridges. The distance between the piers was set to $5.8 \mathrm{~m}$, meeting the layout for construction machinery and the stress requirements of the piles. The height of the bent cap and block were $1.6 \mathrm{~m}$ and $0.9 \mathrm{~m}$, respectively, in accordance with current codes (Ministry of Transport of the People's Republic of China, $2008 ; 2018)$. To evaluate the response of piers under vehicle explosion accurately, gauges were arranged as shown in Figure 3. To represent a real situation during an explosion, the arrangement of longitudinal reinforcements and stirrups was selected according to design drawings widely used for highway bridges. The stirrups were $10 \mathrm{~mm}$ in diameter, with stirrups in the base and top of piers in $4 \mathrm{~m}$ lengths, as shown in Figure 4. The longitudinal reinforcement was $28 \mathrm{~mm}$ in diameter, with a reinforcement ratio of $1.46 \%$. The stirrups and longitudinal reinforcements of the bent cap were selected to be $12 \mathrm{~mm}$ and $28 \mathrm{~mm}$, respectively, with a separation of $15 \mathrm{~cm}$ (Figure 5).

Analyses were performed for each of the five vehicle types described in Table 5. The impact heights and TNT equivalents of representative vehicle classes have been verified by many scholars (DoHS, 2009; Mestrovic et al., 2008; Thomas et al., 2018; Zhou et al., 2017). In order to investigate the performance of the columns and the bent beam under explosion, a consolidation boundary was adopted in the base while a gap was

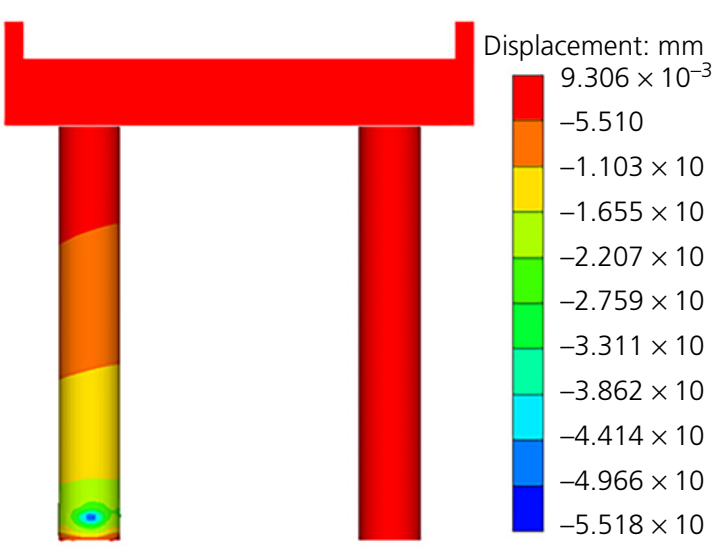

(b)

Figure 7. Contact car explosion: (a) damage mode; (b) displacement. A full-colour version of this figure can be found on the ICE Virtual Library (www.icevirtuallibrary.com) 
established to model the relative displacement between the pier and the bent cap beam. The TNT equivalent was placed near the pier to simulate the worst scenario (Figure 6).

\section{Bridge performance and discussion of results}

The damage to cylindrical RC bridge piers under five scenarios was studied: car explosion, SUV/van explosion, delivery truck explosion, water truck explosion and semi-trailer explosion. With an increase in distance, the explosion energy decreased

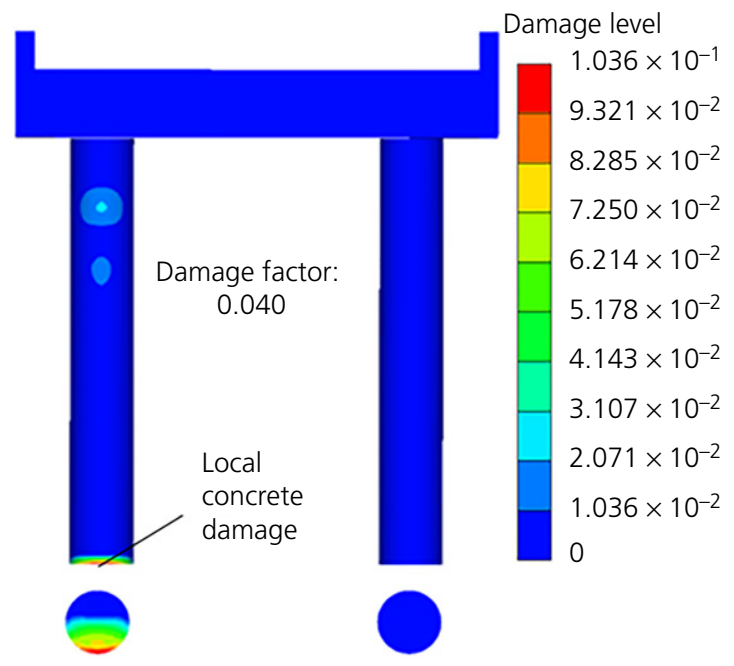

(a) rapidly, while the damage mode and degree of explosion decreased gradually. When the explosive overpressure reached the pier, the structure vibrated violently. Combined with the explosive energy attenuation curve, the analysis time was determined to be $15 \mathrm{~ms}$. The damage zone, displacement and vibration history were used to evaluate the damage modes and mechanisms after the explosions.

After analysis of the explosion damage to the piers, the safety distance for pier explosion resistance was evaluated.

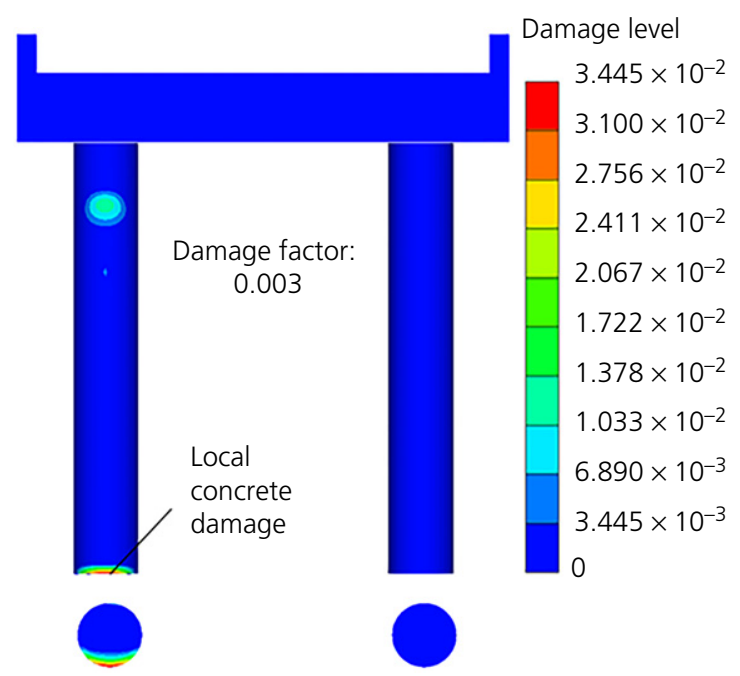

(b)

Figure 8. Damage mode under car explosion at distance of: (a) $1 \mathrm{~m}$; (b) $2 \mathrm{~m}$. A full-colour version of this figure can be found on the ICE Virtual Library (www.icevirtuallibrary.com)

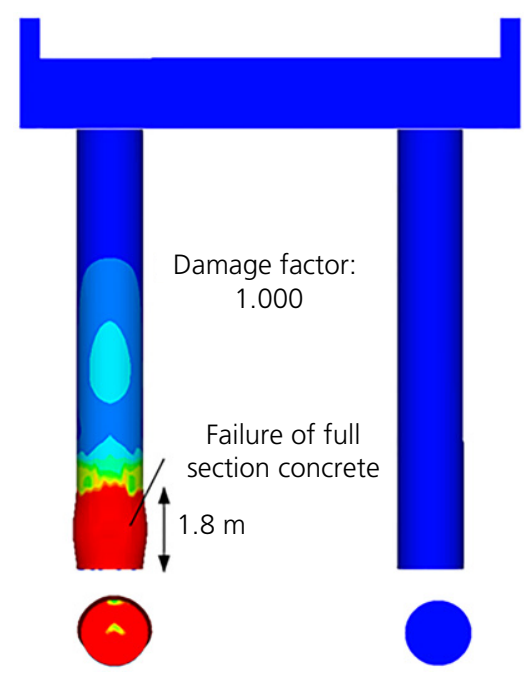

(a)
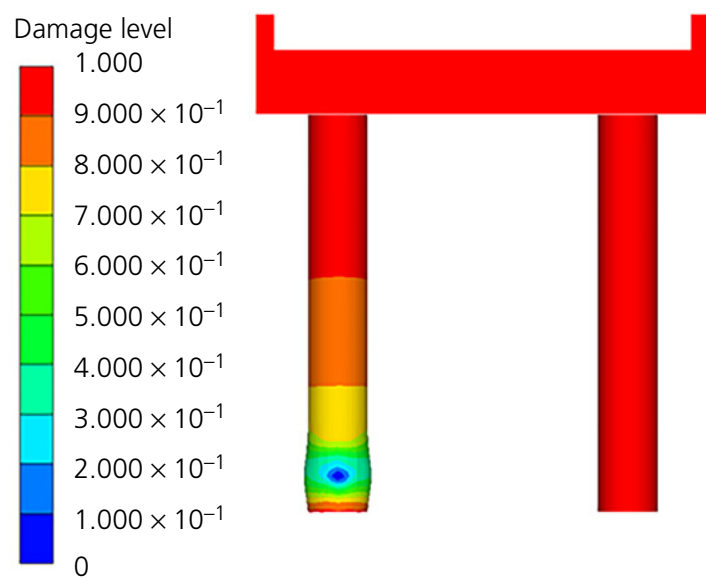

Displacement: $\mathrm{mm}$

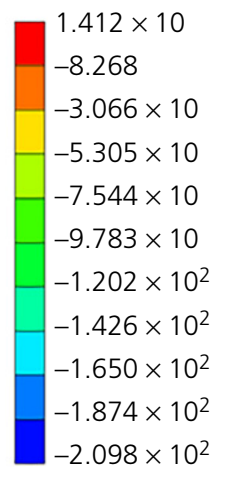

(b)

Figure 9. Contact SUV/van explosion: (a) damage mode; (b) displacement. A full-colour version of this figure can be found on the ICE Virtual Library (www.icevirtuallibrary.com) 
Equation 4 is put forward for a quantitative evaluation of damage under vehicle explosion:

4. $\mathrm{DF}=\frac{\int(\mathrm{DL}) \mathrm{d} A_{\mathrm{S}}}{A_{\mathrm{S}}}$

where DF is the damage factor of the full section, DL is the damage level and $A_{\mathrm{S}}$ is the area of the section. When $\mathrm{DF}=1$, there is failure of the full section; no concrete failure occurs if $\mathrm{DF}=0$.

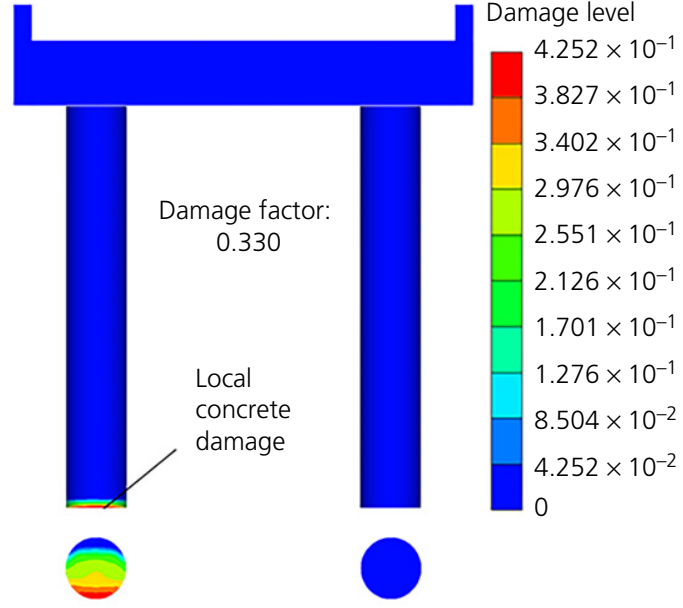

(a)
For the contact car explosion, Figure 7(a) shows that the $\mathrm{RC}$ pier suffered shear failure at the base, with a failure zone of almost $1.2 \mathrm{~m}$. The maximum displacement was $55 \mathrm{~mm}$ after response to the blast wave as a result of shear failure (Figure 7(b)). With an increase in distance, the explosive energy decayed rapidly. The damage factors were found to be 0.040 and 0.003 respectively for distances of $1 \mathrm{~m}$ and $2 \mathrm{~m}$ (Figure 8). The safety distance for the cylindrical $\mathrm{RC}$ bridge pier for a car explosion was thus determined to be $2 \mathrm{~m}$

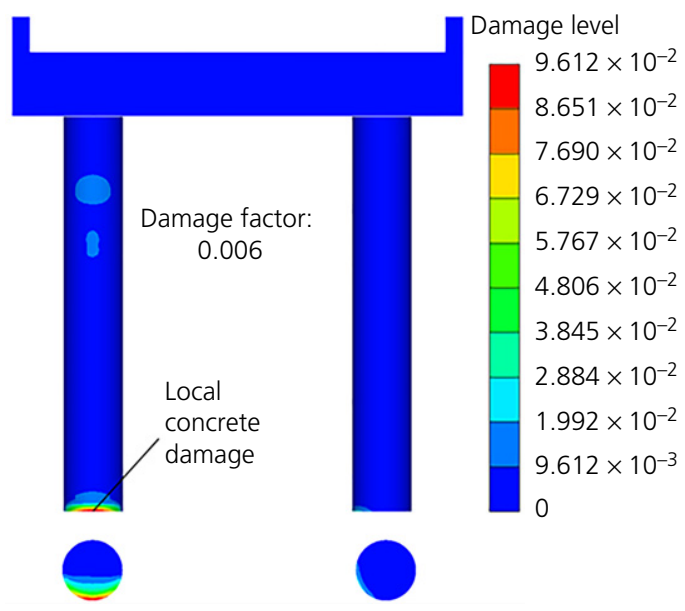

(b)

Figure 10. Damage mode under SUV/van explosion at distance of: (a) $1 \mathrm{~m}$; (b) $3 \mathrm{~m}$. A full-colour version of this figure can be found on the ICE Virtual Library (www.icevirtuallibrary.com)

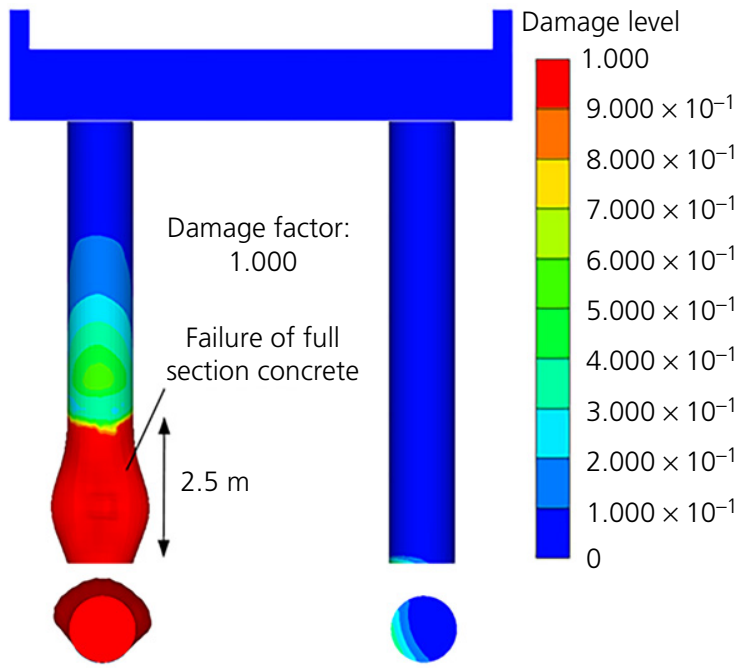

(a)

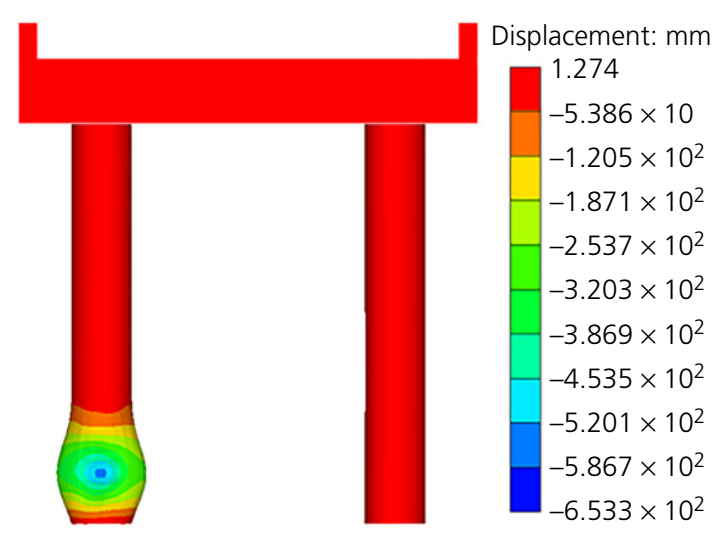

(b)

Figure 11. Contact delivery truck explosion: (a) damage mode; (b) displacement. A full-colour version of this figure can be found on the ICE Virtual Library (www.icevirtuallibrary.com) 
With an increase in TNT equivalent (i.e. SUV/van explosion), the damage zone increased to $1.8 \mathrm{~m}$ at the base of the $\mathrm{RC}$ column (Figure 9). The stirrups yielded in shear and the longitudinal reinforcements showed slight buckling. The final displacement was $210 \mathrm{~mm}$ due to shear failure at the base. For an explosion $1 \mathrm{~m}$ away, the damage factor was 0.330 (Figure 10). At a distance of $3 \mathrm{~m}$, the explosion energy

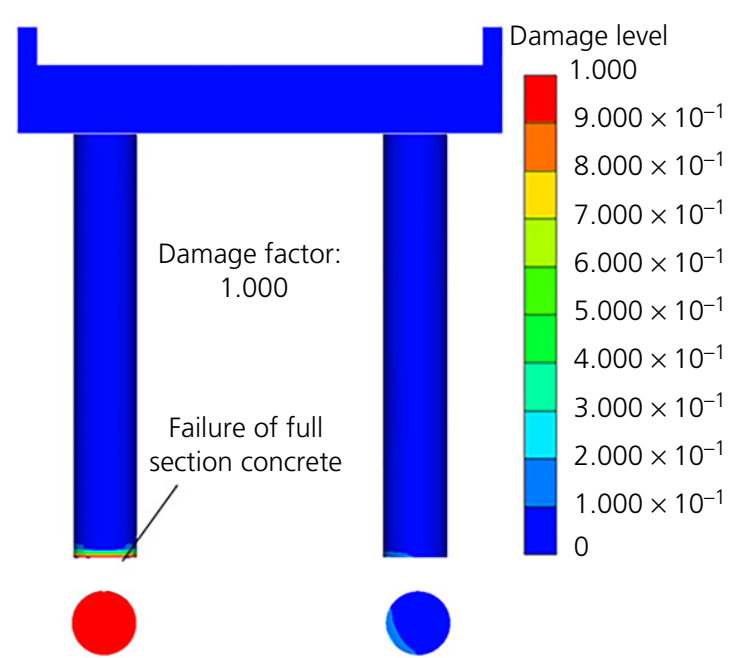

(a) attenuated to result in only slight damage to the pier; the safe distance is thus $3 \mathrm{~m}$.

Compared with a SUV or van, the TNT equivalent of a delivery truck is significantly increased. Figure 11 shows that, for a contact delivery truck explosion, the bottom $2.5 \mathrm{~m}$ of pier concrete was completely damaged and the longitudinal

Figure 12. Damage mode under delivery truck explosion at distance of: (a) $1 \mathrm{~m}$; (b) $4 \mathrm{~m}$. A full-colour version of this figure can be found on the ICE Virtual Library (www.icevirtuallibrary.com)

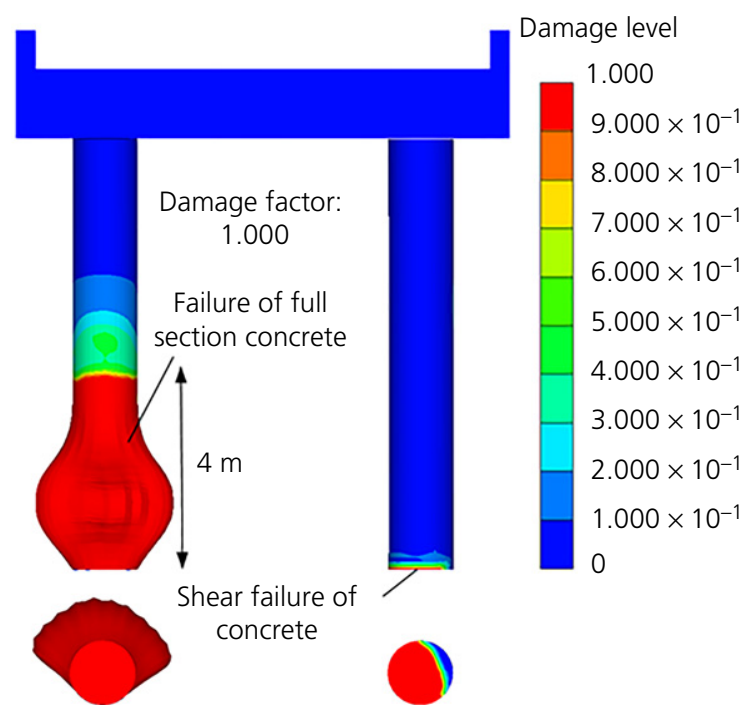

(a)

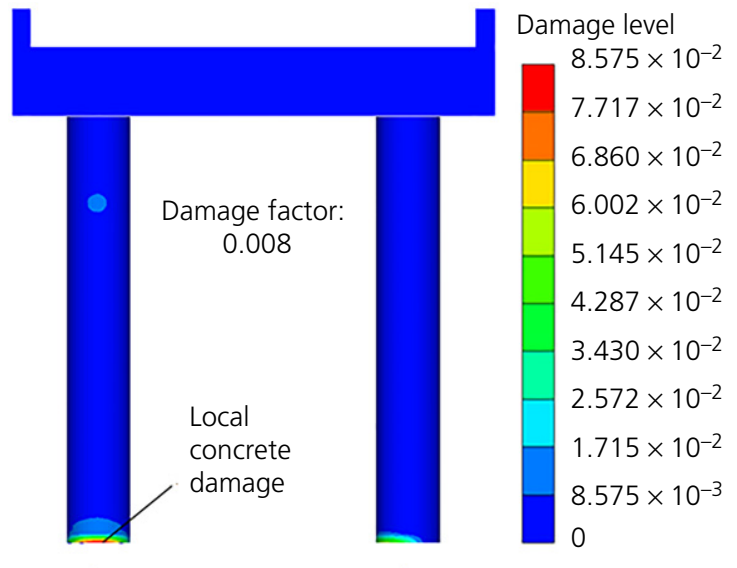

(b) 
reinforcements showed obvious buckling. The punching displacement was $653 \mathrm{~mm}$ at the base while the deformation due to the interaction of the pier and bent cap was $13 \mathrm{~mm}$ inwards, corresponding to the experimental situation shown in Figure 1(b). The damage factors for explosions at distances of $1 \mathrm{~m}$ and $4 \mathrm{~m}$ were found to be 1.000 and 0.008 , respectively (Figure 12). The safety distance for a cylindrical RC bridge pier subjected to delivery truck explosion is thus $4 \mathrm{~m}$.

The explosive TNT equivalent of a water truck is about 2.5 times that of a delivery truck. Under the action of such explosive load, the stirrups were sheared within the bottom $4 \mathrm{~m}$ of the pier, making it difficult for deformation of the longitudinal reinforcement to be restrained, resulting in a displacement of

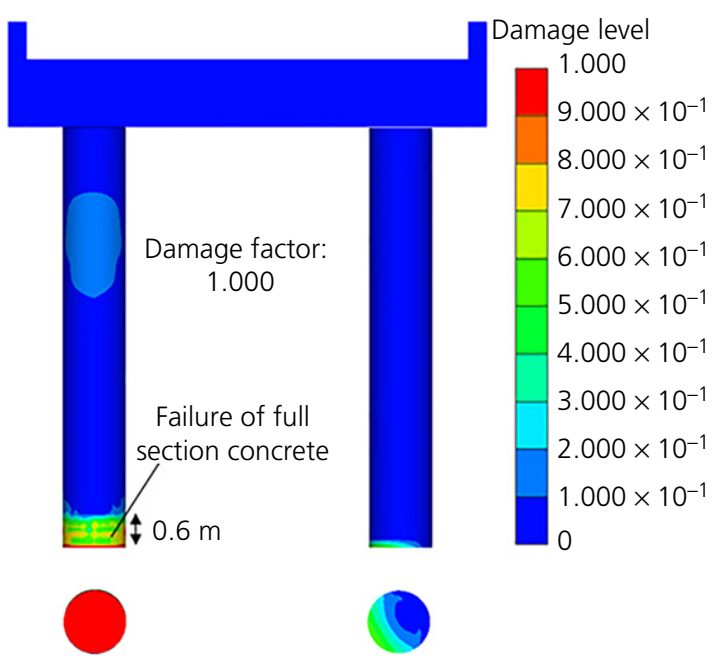

(a)

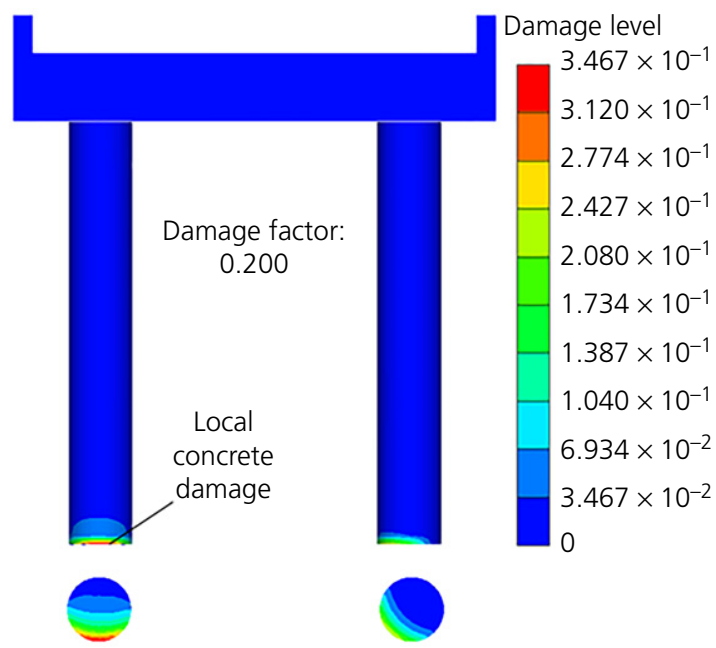

(c)
$123 \mathrm{~mm}$ at the base of columns, as shown in Figure 13. Figure 14 shows the failure modes during non-contact explosion of the water truck: compared with the contact explosion, the non-contact explosions showed shear failure without large deformation. With an increase in distance, local shear failure was only slight; the safety distance was determined to be $8 \mathrm{~m}$.

The piers subjected to explosive impact from a semi-trailer showed very exaggerated displacement. Failure of the stirrups and the shear failure of piers on the other side of the impact resulted in the piers completely losing their bearing capacities, resulting in collapse of the superstructure, as shown in Figure 15. Even with an increase in distance, the explosive
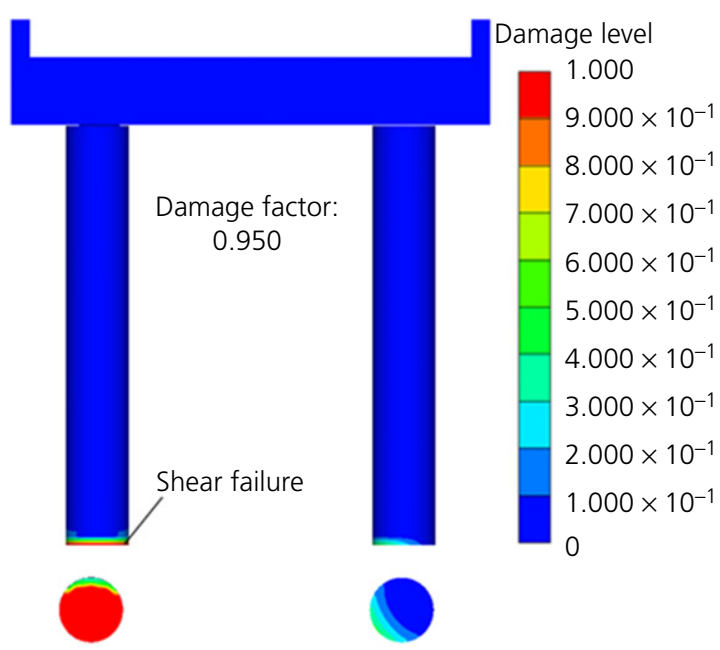

(b)
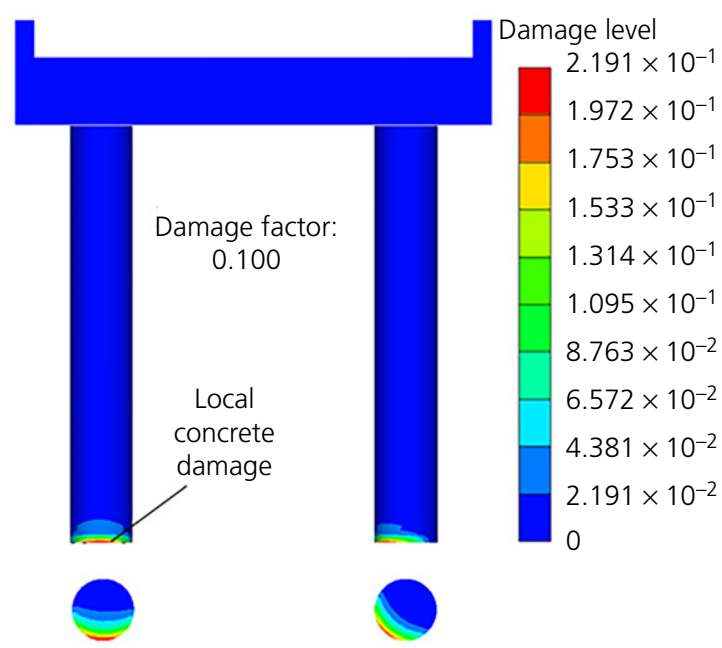

(d)

Figure 14. Damage mode under water truck explosion at distance of: (a) $1 \mathrm{~m}$; (b) 2 m; (c) 4 m; (d) 6 m. A full-colour version of this figure can be found on the ICE Virtual Library (www.icevirtuallibrary.com) 


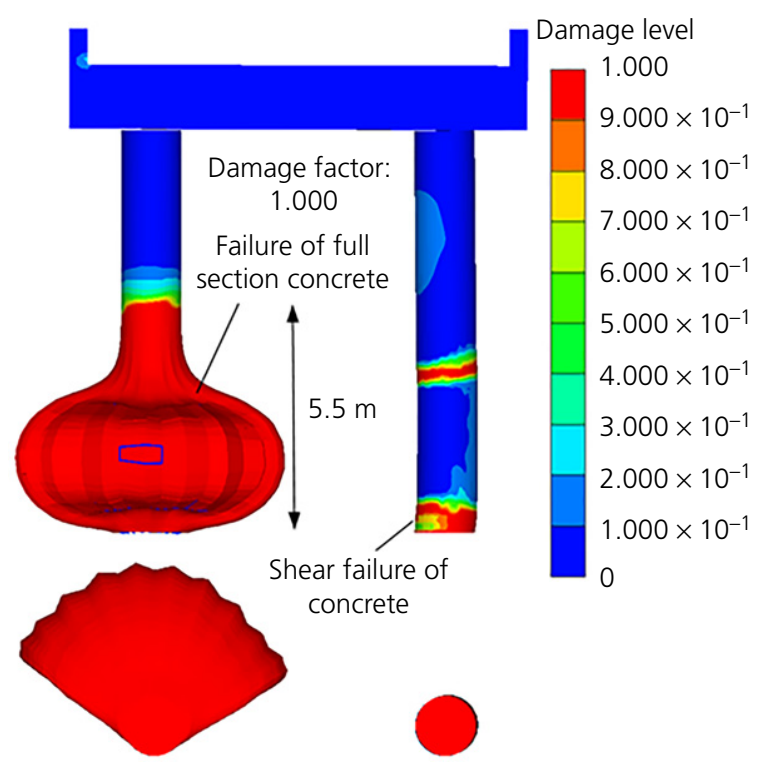

(a)

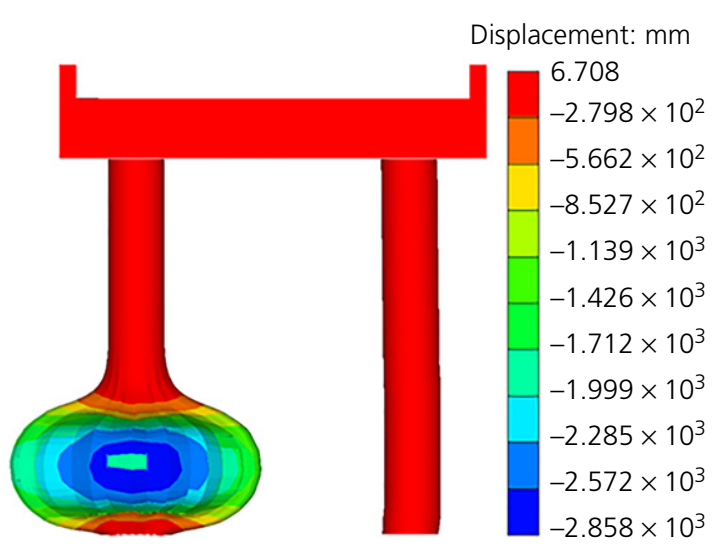

(b)

Figure 15. Contact semi-trailer explosion: (a) damage mode; (b) displacement. A full-colour version of this figure can be found on the ICE Virtual Library (www.icevirtuallibrary.com)

shock wave from the semi-trailer still caused shear failure of the double piers, as shown in Figure 16. For sufficient decay in explosive energy, the safety distance was determined as $14 \mathrm{~m}$, producing a damage factor of 0.003 .

\section{Failure mechanism of cylindrical RC piers subjected to vehicle explosion}

The final failure modes of the structure due to the instantaneous release of explosive impact energy were analysed. During the failure process, the peak pressure and vibration velocity histories were used to investigate the damage mechanisms due to explosion. Figure 17 shows the pressure-time history during the contact vehicle explosions for the car, SUV/van, delivery truck, water truck and semi-trailer: the peak pressures were found to be $2710 \mathrm{MPa}, 4240 \mathrm{MPa}$, $5680 \mathrm{MPa}, 7530 \mathrm{MPa}$ and $10900 \mathrm{MPa}$ respectively. Due to the degradation of stiffness during the explosions, the relationship between explosive overpressure and TNT equivalent was found to be non-linear.

With an increase in distance, the overpressure decayed rapidly, as shown in Figure 18 for the case of the semi-trailer. The overpressure was found to be $1520 \mathrm{MPa}$ for contact explosion while, at a distance of $12 \mathrm{~m}$, the overpressure was just 6.17 MPa. This shows the importance of installing isolation devices to avoid damage due to approaching explosions.

The vibration velocity due to impact energy is also of significance. Figure 19 shows the velocity history of gauges arranged in the pier under contact car explosion. Gauge 3 and gauge 24 were selected to reflect the shear displacement at the base of the column. The velocity history shows that the vibration was consistent with the overpressure. At the peak value of impact overpressure, the displacement velocity reached $8 \mathrm{~mm} / \mathrm{ms}$. With energy attenuation, the vibration velocity gradually decreased to zero. A large punching displacement was observed at the base of the pier while deformation due to the interaction of the pier and bent cap was negligible, corresponding to the experimental result shown in Figure 1(b).

Figure 20 shows the vibration velocity history for a car explosion at a distance of $1 \mathrm{~m}$, again considering gauges 3 , 11 and 24. The vibration velocities of these gauges all fluctuated around zero. As a result, shear failure occurred in the base without large displacement, as also shown in Figure 1(c).

Through an investigation of the failure modes and damage mechanisms due to vehicle explosions, the safety distances are concluded. Figure 21 shows that the safety distances are $2 \mathrm{~m}$, $3 \mathrm{~m}, 4 \mathrm{~m}, 8 \mathrm{~m}$ and $14 \mathrm{~m}$ respectively, foe explosions due to car, SUV/van, delivery truck, water truck and semi-trailer impact. This paper is meaningful to explosion-resistant design and damage assessment of existing highway cylindrical RC piers under vehicle explosion.

\section{Conclusions}

The failure modes and safety distances of cylindrical RC bridge piers subjected to vehicle explosions were investigated. TNT equivalents were selected to represent the explosion of a 
Safety distances of cylindrical reinforced concrete piers under vehicle explosion

Zhu, Li and He

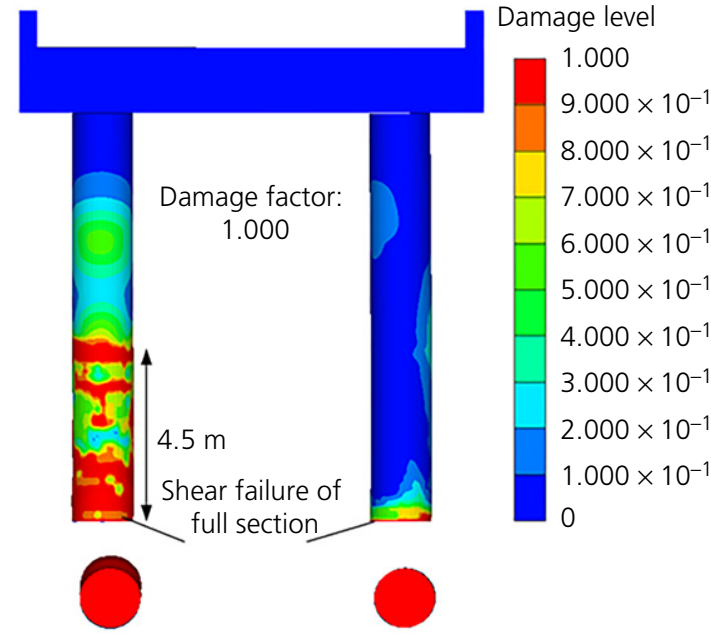

(a)

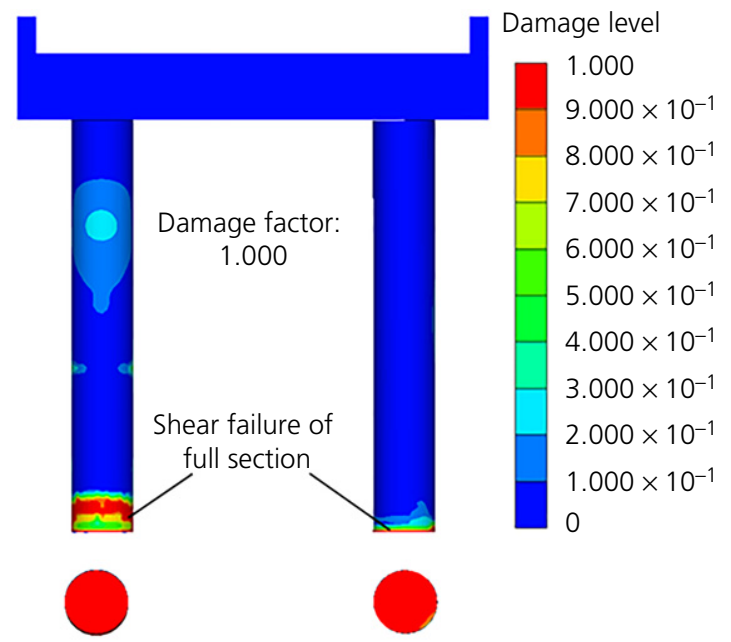

(c)

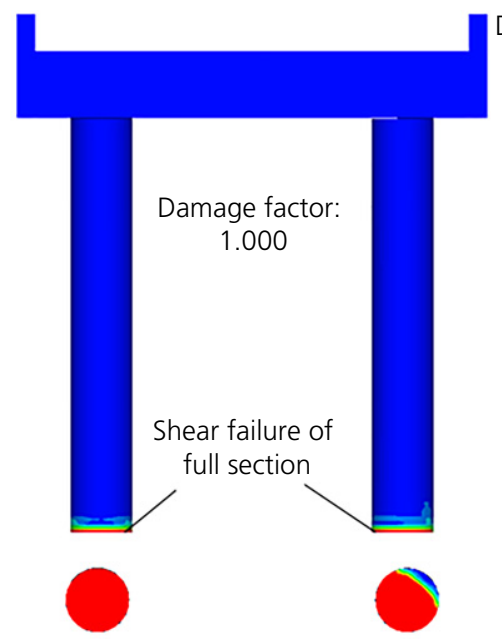

(e)

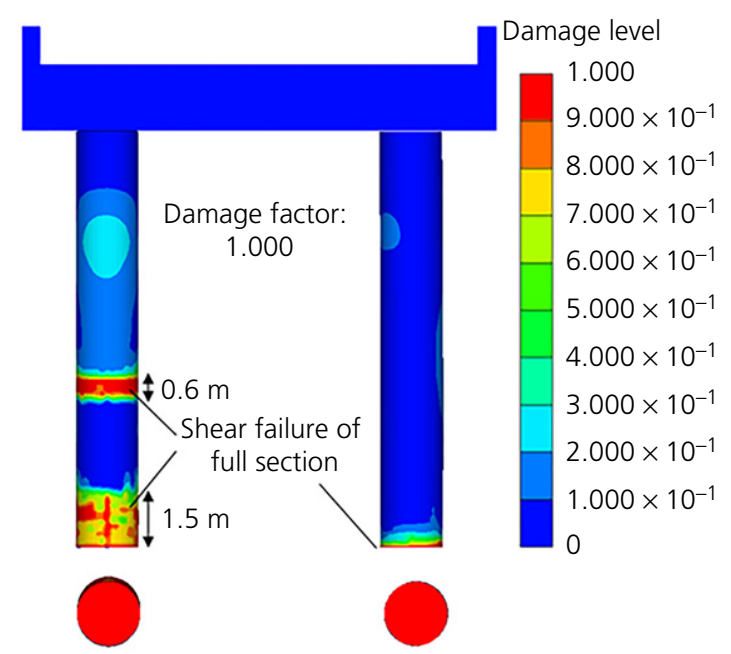

(b)

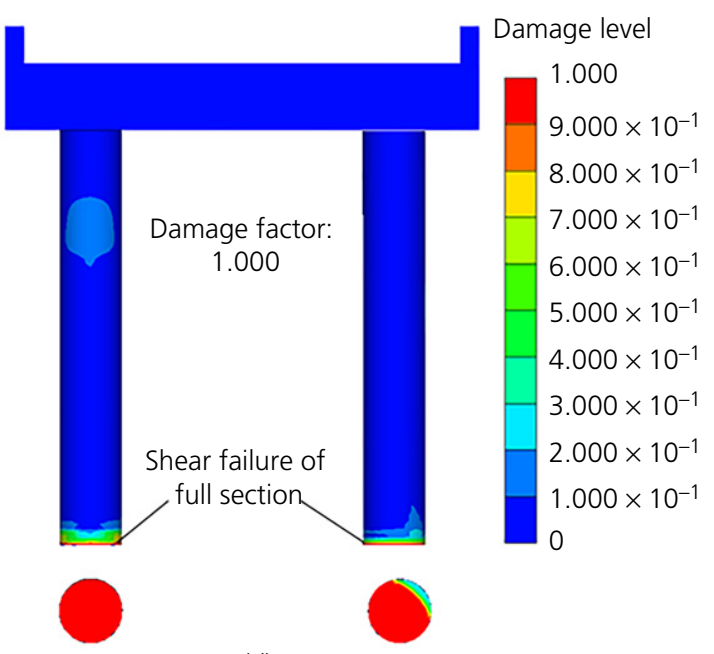

(d)

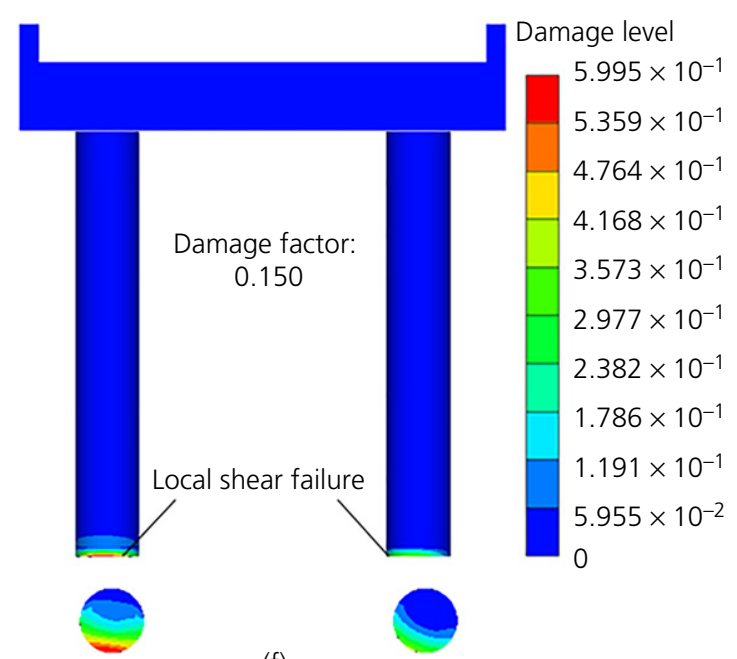

(f)

Figure 16. Damage mode under semi-trailer explosion at distance of: (a) 1 m; (b) 2 m; (c) 4 m; (d) 6 m; (e) 8 m; (f) 12 m. A full-colour version of this figure can be found on the ICE Virtual Library (www.icevirtuallibrary.com) 


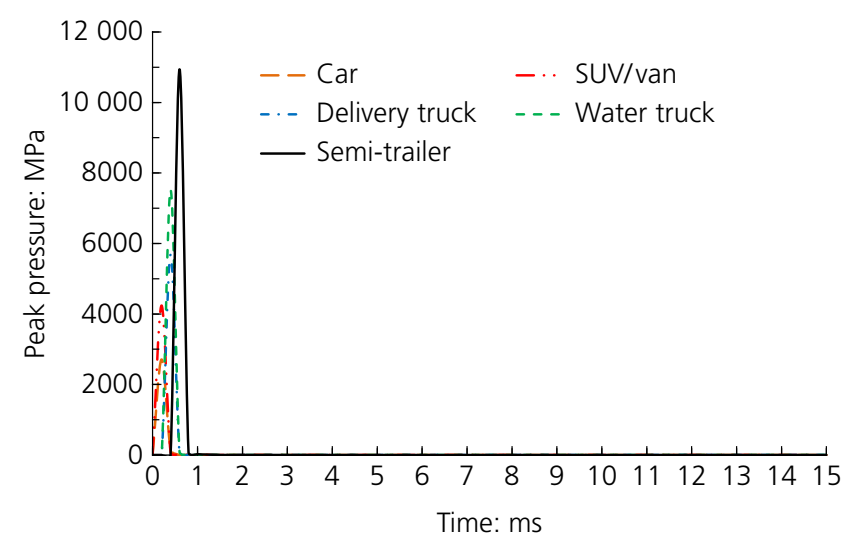

Figure 17. Peak pressure-time history during contact vehicle explosions

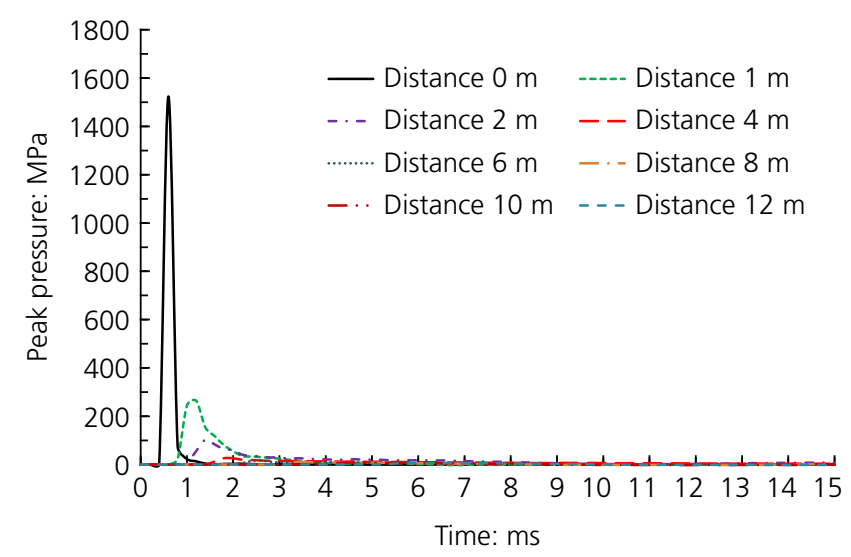

Figure 18. Peak pressure-time history during explosion of semitrailer

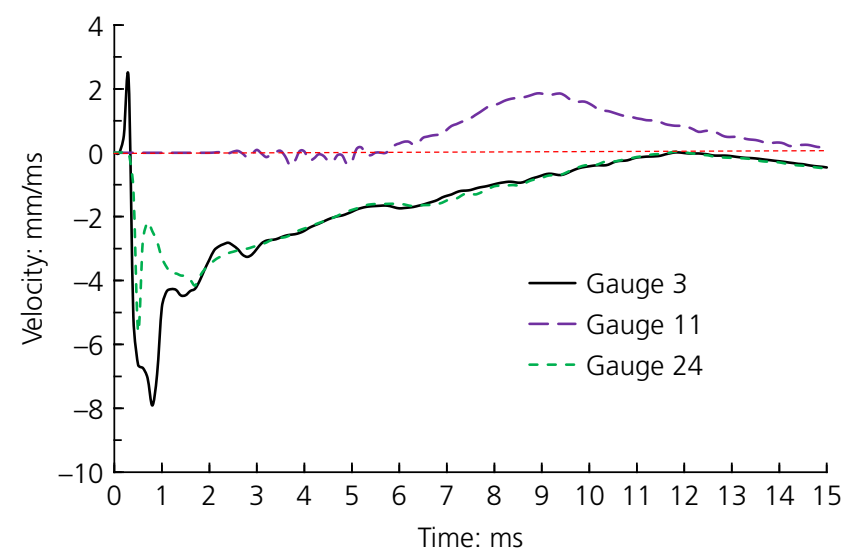

Figure 19. Vibration velocity-time history under contact car explosion

car, SUV/van, delivery truck, water truck and semi-trailer. To precisely reflect the fluid-solid coupling characteristics during blast loading, the multi-Euler domain method was

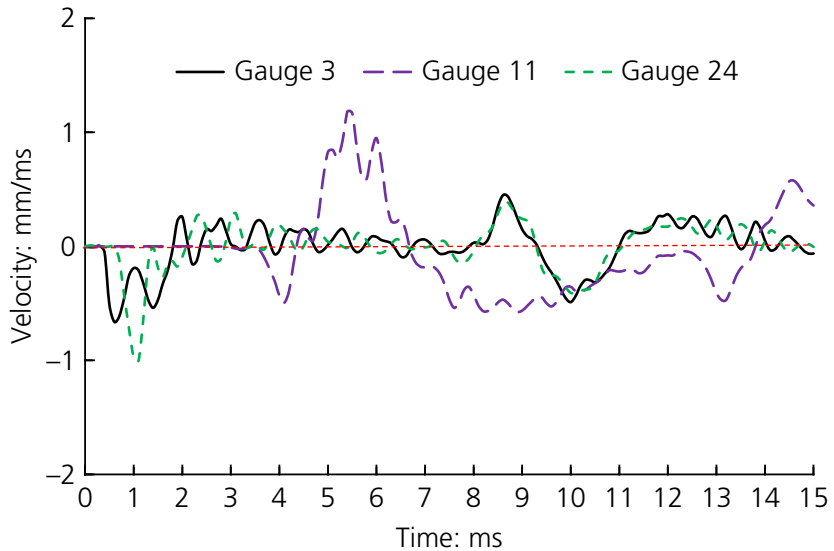

Figure 20. Vibration velocity-time history under car explosion at a distance of $1 \mathrm{~m}$

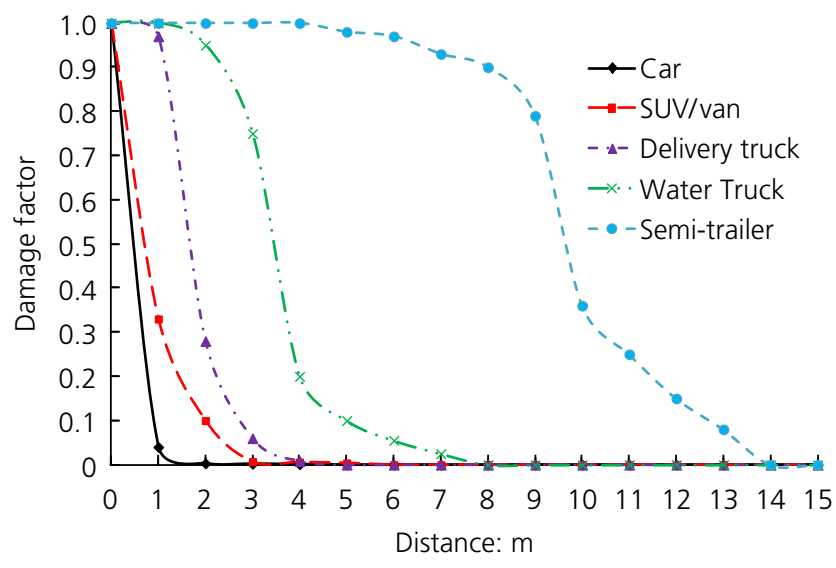

Figure 21. Damage factors due to vehicle explosions as a function of distance

adopted. The following conclusions were drawn from this study.

(a) Due to vehicle explosion, the cylindrical RC piers showed three failure modes at the base: $(a)$ full-section punching-shear failure and large displacement,

(b) shear failure of the full section of concrete and (c) local shear failure of the concrete. The shear capacity of piers should thus be improved if they could suffer damage due to intentional or unintentional vehicle explosion.

(b) With an increase in distance from the explosion, the overpressure and damage modes decayed rapidly. It is thus particularly important to install isolation devices to avoid approaching vehicle explosions.

(c) For different anti-explosion requirements and traffic needs, protection from vehicle explosions should be suitably applied. Safety distances were determined in this work and were found to be $2 \mathrm{~m}, 3 \mathrm{~m}, 4 \mathrm{~m}, 8 \mathrm{~m}$ and 
$14 \mathrm{~m}$ for car, SUV/van, delivery truck, water truck and semi-trailer explosions, respectively.

\section{Acknowledgement}

The authors gratefully acknowledge the financial support provided by the Fundamental Research Funds for the Central Universities of China (grant 300102218214) and Guangdong Provincial Transportation and Transportation Office Technology Funding (project 2016-02-016). The help of engineers and technicians at the Key Laboratory of Bridge Detection Reinforcement Technology Ministry of Communications of Chang'an University is also highly appreciated.

\section{REFERENCES}

Bao XL and Li B (2010) Residual strength of blast damaged reinforced concrete columns. International Journal of Impact Engineering 37(3): 295-358

Carta G and Stochino F (2013) Theoretical models to predict the flexural failure of reinforced concrete beams under blast loads. Engineering Structures 49: 306-315.

DoHS (U. S. Department of Homeland Security) (2009) Bomb Threat Standoff Chart. DoHS, Washington, DC, USA.

Forni D, Chiaia B and Cadoni E (2016) Strain rate behaviour in tension of S335 steel: base for progressive collapse analysis. Engineering Structures 119: 164-173.

Forni D, Chiaia B and Cadoni E (2017) Blast effects on steel columns under fire conditions. Journal of Constructional Steel Research 136: $1-10$.

Fujikura S and Bruneau M (2011) Experimental investigation of seismically resistant bridge piers under blast loading. Journal of Bridge Engineering 16(1): 63-71.

Hashemi SK, Bradford MA and Valipour HR (2017) Dynamic response of cable-stayed bridge under blast load: effects of pylon geometry. Engineering Structures 137: 719-736.

Kyei C and Braimah A (2017) Effects of transverse reinforcement spacing on the response of reinforced concrete columns subjected to blast loading. Engineering Structures 142: 148-164.

Li J, Wu CQ and Hao H (2017a) Experimental and numerical study on steel wire mesh reinforced concrete slab under contact explosion. Materials and design 116: 77-91.

Li J, Hao H and Wu CQ (2017b) Numerical study of precast segmental column under blast loads. Engineering Structures 134: 125-137.

Li Y and He SH (2018) Research of steel-concrete composite bridge under blasting loads. Advances in Civil Engineering 5748278, https://doi.org/10.1155/2018/5748278.

Liu HB, Torres DM and Agrawal AK (2015) Simplified blast-load effects on the column and bent beam of highway bridges. Journal of Bridge Engineering 123(9): 06015001.

Liu L, Zong ZH and Li MH (2018) Numerical study of damage modes and assessment of circular RC pier under noncontact explosions. Journal of Bridge Engineering 123(9): 04018061.

Mestrovic D, Cizmar D and Miculinic L (2008) Reliability of concrete columns under vehicle impact. In Proceedings of 10th International Conference on Structures Under Shock and Impact, Portugal.

Ministry of Transport of the People's Republic of China (2008) JTG/T B02-01: Guidelines for seismic design of highway bridges. Ministry of Transport of the People's Republic of China, Beijing, China.

Ministry of Transport of the People's Republic of China (2018) JTG 33622018: Specifications for design of highway reinforced concrete and prestressed concrete bridge and culverts. Ministry of Transport of the People's Republic of China, Beijing, China.
Nystrom U and Gylltoft K (2011) Comparative numerical studies of projectile impacts on plain and steel-fiber reinforced concrete. International Journal of Impact Engineering 38(3): 95-105.

Pan YX, Chan BYB and Cheung MMS (2013) Blast loading effects on an $\mathrm{RC}$ slab-on-girder bridge superstructure using the multi-Euler domain method. Journal of Bridge Engineering 18(11): 1152-1163.

Pan YX, Ventura CE and Cheung MMS (2017) Performance of highway bridges subjected to blast loads. Engineering Structures 151: 788-801.

Shiravand MR and Parvanehro P (2017) Numerical study on damage mechanism of post-tensioned concrete box bridges under close-in deck explosion. Engineering Failure Analysis 81: 103-116.

Son J and Astaneh-Asl A (2017) Blast resistance of steel orthotropic bridge decks. Journal of Bridge Engineering 17(4): 589-598.

Thomas RJ, Kylie S and Andrew DS (2018) Reliability analysis of circular reinforced concrete columns subject to sequential vehicular impact and blast loading. Engineering Structures 168: 838-851.

Tu ZG and Lu Y (2010) Modifications of RHT material model for improved numerical simulation of dynamic response of concrete. International Journal of Impact Engineering 37(10): 1072-1082.

Williamson EB, Bayrak O and Williams GD (2011a) Performance of bridge columns subjected to blast loads. I: experimental program. Journal of Bridge Engineering 16(6): 693-703.

Williamson EB, Bayrak O and Williams GD (2011b) Performance of bridge columns subjected to blast loads. II: result and recommendations. Journal of Bridge Engineering 16(6): 703-710.

Williams GD and Williamson EB (2012) Procedure for predicting blast loads acting on bridge columns. Journal of Bridge Engineering 17(3): 490-499.

Winget DG, Marchand KA and Williamson EB (2005) Analysis and design of critical bridges subjected to blast loads. Journal of Structural Engineering 131(8): 1243-1255.

Zhou DY, Li RW, Wang J and Guo CT (2017) Study on impact behavior and impact force of bridge pier subjected to vehicle collision. Shock and Vibration 7085392.

Zhu Z, Li Y and He SH (2019) Analysis of the failure mechanism of multi-beam steel-concrete composite bridge under car explosion. Advances in Structural Engineering 23(3): 538-548.

Zong ZH, Tang B, Cao C and Liu L (2017) Experimental on blastresistance performance of reinforced concrete piers. China Journal of Highway Transport 30(9): 51-60.

\section{How can you contribute?}

To discuss this paper, please email up to 500 words to the editor at journals@ice.org.uk. Your contribution will be forwarded to the author(s) for a reply and, if considered appropriate by the editorial board, it will be published as discussion in a future issue of the journal.

Proceedings journals rely entirely on contributions from the civil engineering profession (and allied disciplines). Information about how to submit your paper online is available at www.icevirtuallibrary.com/page/authors, where you will also find detailed author guidelines. 